\title{
STUDI PERBANDINGAN PERENCANAAN BANGUNAN BAJA SISTEM SPECIAL MOMENT FRAMES DAN SPECIAL PLATE SHEAR WALLS
}

\author{
Deny Anarista Sitorus ${ }^{1}$, Wiryanto Dewobroto ${ }^{2}$ \\ ${ }^{1}$ Program Studi Magister Teknik Sipil Universitas Tarumanagara \\ Email: denysitorus@gmail.com \\ ${ }^{2}$ Dosen Teknik Sipil Universitas Pelita Harapan \\ Email: wiryanto.dewobroto@uph.edu
}

\begin{abstract}
Indonesia is an earthquake-prone area, therefore, building construction using seismic force resisting system is considered important. Generally, the building structure is reinforced concrete, while steel using the special moment frames (SMF) system is more commonly found as seismic force resisting system. Yet according to ASCE / SEI 7-10 regulations, there are choices of seismic force resisting system for steel buildings such as special plate shear walls (SPSW), special truss moment frames (STMF) and other special systems. This study will show a comparison of SMF and SPSW system building planning in studying the potential use of these two systems in Indonesia. The spatial configuration between columns was chosen to produce a variety of SMF system building designs so as to produce an economical structure. From the results of a comparative study of planning, it is known that the configuration of the building structure with a short span length between columns, the SMF system is more economical when compared to the SPSW system. However, for large span length of span between columns the use of the SPSW system can be an alternative.
\end{abstract}

Keywords: earthquake, special moment frames, special plate shear walls

\begin{abstract}
ABSTRAK
Indonesia merupakan wilayah rawan gempa, sehingga konstruksi bangunan memakai sistem penahan gaya seismik dianggap penting. Umumnya, struktur bangunan adalah beton bertulang, adapun baja penggunaan sistem special moment frames (SMF) lebih banyak dijumpai sebagai sistem penahan gaya seismik. Padahal menurut peraturan ASCE/SEI 7-10 terdapat pilihan sistem penahan gaya seismik untuk bangunan baja seperti special plate shear walls (SPSW), special truss moment frames (STMF) dan sistem khususnya lainnya. Studi ini akan memperlihatkan perbandingan perencanaan bangunan sistem SMF dan SPSW dalam mempelajari potensi penggunaan kedua sistem ini di Indonesia. Konfigurasi bentang antar kolom dipilih agar menghasilkan variasi desain bangunan sistem SMF sehingga menghasilkan struktur yang ekonomis. Dari hasil studi perbandingan perencanaan, diketahui bahwa konfigurasi struktur bangunan dengan panjang bentang antar kolom yang pendek, maka sistem SMF lebih ekonomis bila dibandingkan terhadap sistem SPSW. Akan tetapi, untuk panjang bentang antar kolom yang besar penggunaan sistem SPSW dapat menjadi alternatif.
\end{abstract}

Kata kunci: gempa, special moment frames, special plate shear walls

\section{PENDAHULUAN \\ Latar Belakang}

Berdasarkan peraturan gempa di Amerika yaitu ASCE/SEI 7 (ASCE, 2010) dan ANSI/AISC 341 (AISC, 2010b), terdapat pilihan sistem penahan gaya seismik yang tersedia yaitu sistem special moment frames (SMF), special plate shear walls (SPSW) dan sistem khusus lainnya. Di Indonesia, penggunaan sistem SMF lebih popular dijumpai bila dibandingkan terhadap sistem SPSW yang sudah relatif banyak diaplikasikan di Jepang maupun Amerika pada bangunan bertingkat. Perbedaan dari kedua sistem ini terletak pada elemen khusus yang sengaja diperlemah untuk bekerja sebagai fuse dengan kondisi leleh yang direncanakan pada sistem SMF terbatas pada kedua ujung balok, sedangkan pada sistem SPSW pelelehan terjadi pada pelat baja yang direncanakan khusus sebagai lokasi disipasi energi gempa. Kedua sistem ini merupakan solusi terhadap ketahanan bangunan baja tahan gempa sesuai diperlihatkan pada Gambar 1 . 


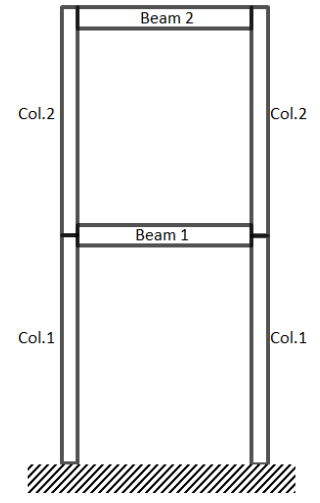

(a) Special moment frames

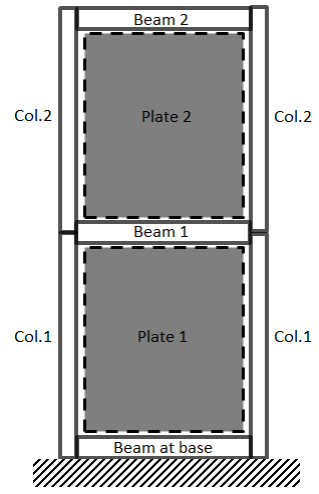

(b) Special plate shear walls

Gambar 1. Skematik sistem struktur SMF dan SPSW

Penggunaan SPSW pada bangunan bertingkat telah terbukti menghasilkan performa yang baik terhadap ketahanan gempa. Di Amerika, SPSW dipilih terhadap perbaikan sistem struktur bangunan rumah sakit yang terdiri dari 6 tingkat lantai, lainnya seperti di Jepang telah sukses diterapkan pada bangunan perkantoran 35 tingkat lantai pasca gempa Kobe tahun 1995 (AISC, 2006). Konstruksi bangunan baja dengan sistem jenis ini masih merupakan hal baru dan perlu diperkenalkan sebagai alternatif dalam pemilihan sistem penahan gaya seismik di Indonesia. Untuk mengetahui potensi penggunaan sistem SMF dan SPSW, maka diperlukan studi perbandingan perencanaan agar mendapatkan struktur yang tepat terhadap konfigurasi struktur bangunan.

\section{SISTEM SPECIAL MOMENT FRAMES}

Studi kasus bangunan dilakukan terhadap sistem SMF yang telah direncanakan sebelumnya oleh Moestopo (2012) sebagai dasar perhitungan. Bangunan yang dipilih merupakan gedung perkantoran dengan 4 (empat) tingkat lantai (termasuk lantai atap) dan memiliki luas tiap tingkat lantai adalah $792 \mathrm{~m} 2$. Lokasi bangunan yang dipilih adalah Jakarta dan dibangun di atas tanah lunak. Sistem SMF diposisikan pada perimeter luar bangunan yang identik terhadap arah yang ditinjau. Beban mati yang digunakan di tiap tingkat lantai adalah 1,5 $\mathrm{kPa}$ berupa lantai beton dengan tebal $12 \mathrm{~cm}$ di atas metal deck. Balok lantai diperhitungkan sebagai struktur komposit yang didefinisikan sebagai penahan beban gravitasi saja. Beban dinding eksterior sebesar 2,5 $\mathrm{kPa}$ yang terdistribusi merata di atas balok yang dihitung berdasarkan setengah tinggi antar tingkat lantai. Beban hidup diambil sebesar 2,4 kPa untuk lantai perkantoran, dan 0,96 kPa di tingkat lantai atap.

Perencanaan dilanjutkan untuk mengetahui pengaruh konfigurasi bentang antar kolom sistem SMF berdasarkan evaluasi terhadap volume keseluruhan struktur sehingga menghasilkan perbandingan terhadap kedua sistem jenis ini. Strategi yang dilakukan berdasarkan studi parametrik terhadap modifikasi konfigurasi struktur berdasarkan variasi panjang bentang antar kolom yang disebut sebagai studi parametrik. Parameter yang dipilih adalah luasan dasar dan tingkat lantai yang sama. Bangunan dengan modifikasi panjang antar kolom sebesar 5,5 meter disebut sebagai sistem SMF tipe 1, dan 11 meter untuk sistem SMF tipe 2 sesuai denah bangunan yang diperlihatkan pada Gambar 2 dan Gambar 3 berikut ini: 


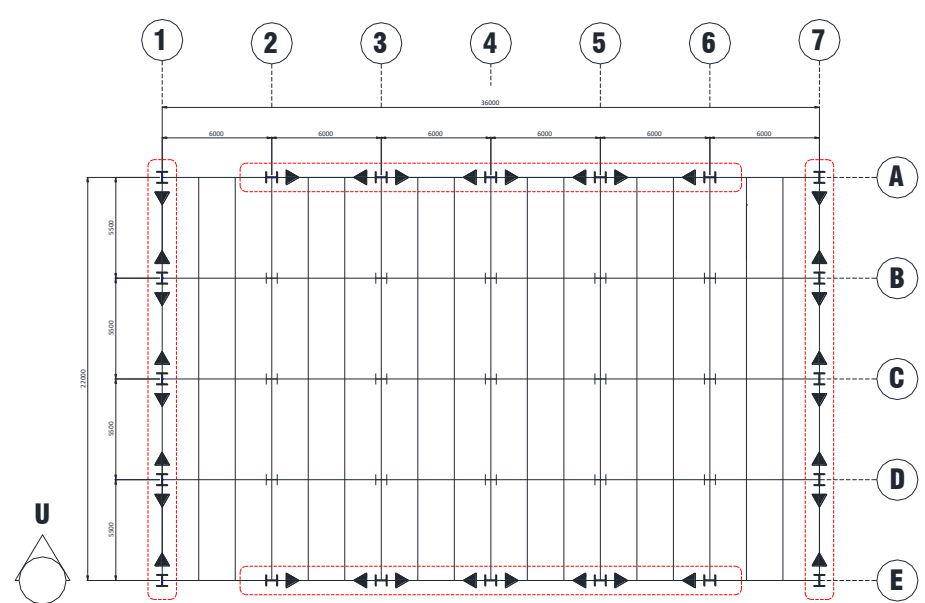

Gambar 2. Denah bangunan sistem SMF tipe 1

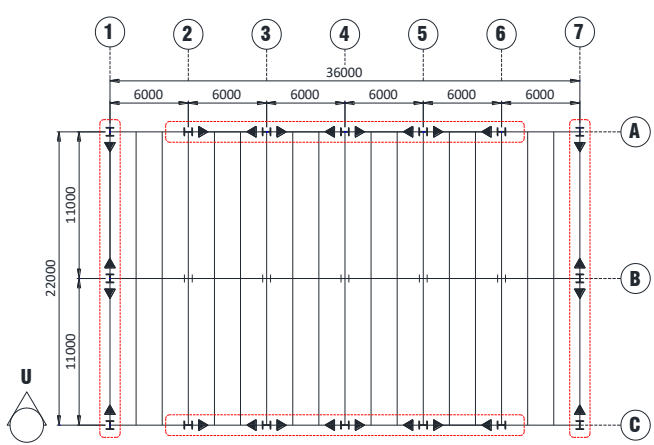

Gambar 3. Denah bangunan sistem SMF tipe 2

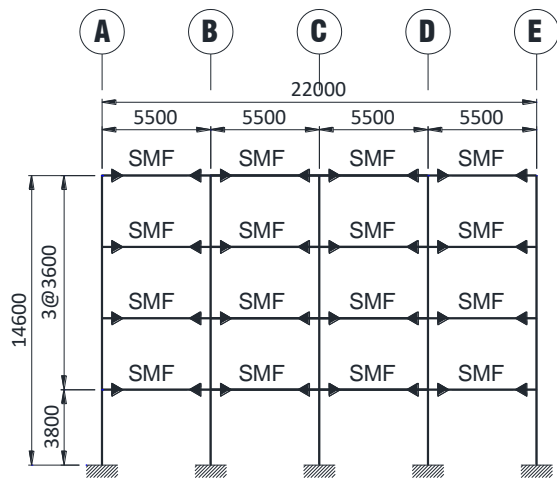

(a) Portal as 1 dan 7 SMF tipe 1

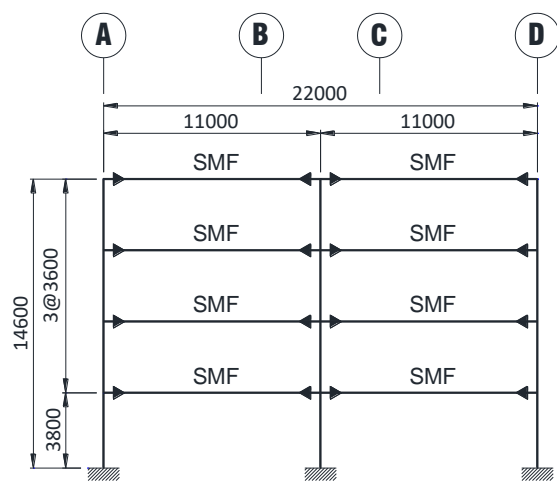

(a) Portal as 1 dan 7 SMF tipe 2

Gambar 4. Potongan melintang bangunan SMF

Beban gempa dihitung berdasarkan prosedur gaya lateral ekivalen menurut peraturan ASCE/SEI 7 (ASCE, 2010). Dengan menganggap luasan dasar dan tingkat lantai yang sama, maka gaya geser dasar desain, $V$, yang digunakan sebesar $1239,21 \mathrm{kN}$ sesuai Tabel 1 dengan faktor keutamaan yang dipilih, $I_{e}$, adalah 1.0 dan periode getar, $T_{\text {maks. }}=0,87$ detik. Faktor modifikasi respons, $R$, adalah 8 untuk struktur daktail, faktor kuat lebih sistem, $\Omega_{0}$, sebesar 3 dan faktor pembesaran defleksi, $C_{d}$, yang digunakan adalah 5,5 . Berikut gaya lateral yang dikenakan pada sistem SMF sesuai Tabel 1:

Tabel 1. 
Beban gempa desain sistem SMF

\begin{tabular}{llllllll}
\hline Lantai & $h_{i}(\mathrm{~m})$ & $W_{i}(\mathrm{~kg})$ & $W_{i} h_{i}(\mathrm{~kg} . \mathrm{m})$ & $W_{i} h_{i}^{k}(\mathrm{~kg} . \mathrm{m})$ & $C_{v x}$ & $F_{i}(\mathrm{kN})$ & $V_{i}(\mathrm{kN})$ \\
\hline 4 & 14600 & 328710 & 322115.47 & 7859713.175 & 0.353 & 436.896 & - \\
3 & 11000 & 441587 & 524135.74 & 7551360.76 & 0.339 & 419.756 & 436.896 \\
2 & 7400 & 441587 & 524135.74 & 4722659.515 & 0.212 & 262.517 & 856.651 \\
1 & 3800 & 444934 & 527520.18 & 2161520.568 & 0.097 & 120.152 & 1119.169 \\
Total & & 1656818 & & 22295254.02 & 1 & & 1239.321 \\
\hline
\end{tabular}

Perencanaan sistem SMF termasuk penahan gravitasi ditentukan berdasarkan analisis 3 (tiga) dimensi dengan bantuan program $E T A B S$. Sistem lantai didefinisikan sebagai diafragma kaku dengan eksentrisitas rencana sebesar 5\% terhadap panjang bangunan dan diambil tegak lurus terhadap arah beban gempa yang ditinjau. Hubungan balok-kolom SMF direncanakan dengan sambungan baut terprakualifikasi menurut peraturan ANSI/AISC 358 (AISC, 2010c). Material baja direncanakan dengan $F_{y}=250 \mathrm{MPa}, R_{y}=1,5$ dan $E=200.000 \mathrm{MPa}$. Komponen struktur sistem SMF dipilih berdasarkan tinjauan terhadap simpangan antar tingkat lantai (rigid zone factor $=0$ ), sehingga bangunan dapat memberikan kekakuan yang cukup dalam memenuhi kriteria batasan simpangan menurut peraturan ASCE/SEI 7 (ASCE, 2010). Profil baja yang digunakan dalam perencanaan bangunan sistem SMF sesuai Tabel 2, 3, dan 4 berikut:

Tabel 2. Profil baja sistem SMF tipe 1

\begin{tabular}{lll}
\hline Tingkat lantai & Balok SMF & Kolom SMF \\
\hline 1 & WF $450 \times 200$ & WF $588 \times 300$ \\
2 & WF $450 \times 200$ & WF $588 \times 300$ \\
3 & WF $450 \times 200$ & WF $588 \times 300$ \\
4 & WF $450 \times 200$ & WF $588 \times 300$ \\
\hline
\end{tabular}

Tabel 3. Profil baja sistem SMF tipe 2

\begin{tabular}{lll}
\hline Tingkat lantai & Balok SMF & Kolom SMF \\
\hline 1 & WF $600 \times 200$ & WF $800 \times 300$ \\
2 & WF $600 \times 200$ & WF $800 \times 300$ \\
3 & WF $600 \times 200$ & WF $800 \times 300$ \\
4 & WF $600 \times 200$ & WF $800 \times 300$ \\
\hline
\end{tabular}

Tabel 4. Profil baja sistem penahan gravitasi

\begin{tabular}{|c|c|c|c|c|c|}
\hline \multirow[b]{2}{*}{ Tingkat lantai } & \multicolumn{3}{|c|}{ Bangunan sistem SMF tipe 1} & \multicolumn{2}{|c|}{ Bangunan sistem SMF tipe 2} \\
\hline & Balok lantai BT & Balok lantai US & Kolom OMF & Balok lantai & Kolom OMF \\
\hline 1 & WF 284 x 124 & WF $300 \times 150$ & H $300 \times 300$ & WF $600 \times 200$ & H $350 \times 350$ \\
\hline 2 & WF 284 x 124 & WF $300 \times 150$ & H $300 \times 300$ & WF $600 \times 200$ & H $350 \times 350$ \\
\hline 3 & WF 284 x 124 & WF $300 \times 150$ & H $300 \times 300$ & WF $600 \times 200$ & Н $350 \times 350$ \\
\hline 4 & WF 284 x 124 & WF $300 \times 150$ & H $300 \times 300$ & WF $600 \times 200$ & Н $350 \times 350$ \\
\hline
\end{tabular}



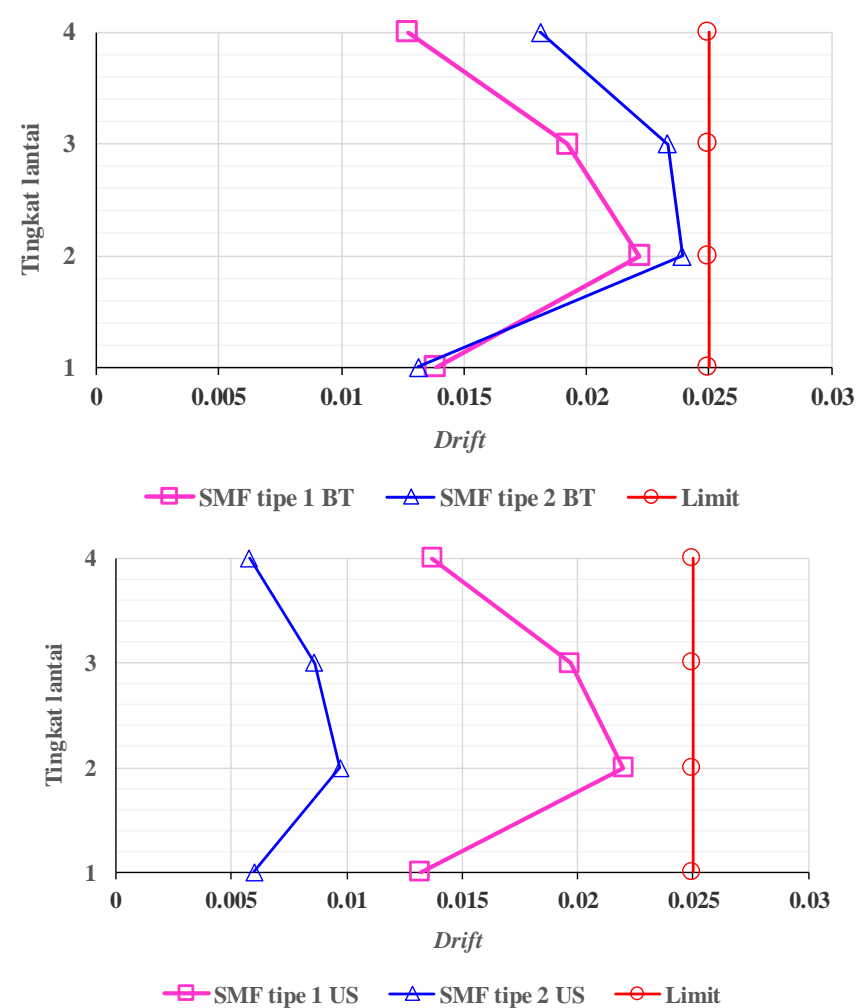

Gambar 5. Storey drift sistem SMF

Dalam analisis struktur, pengaruh P-delta tidak disertakan dikarenakan hasil pemeriksaan terhadap sensivitas bangunan menunjukkan nilai $\theta<0,1$ dan $\theta<\theta_{\text {maks. }}$ Kombinasi beban yang disertakan untuk menghasilkan beban ultimit berdasarkan perencanaan sebelumnya oleh Moestopo (2012). Selanjutnya, analisis modal berdasarkan beban mati yang disertakan sebesar $100 \%$ dan beban hidup 30\% dengan menghasilkan periode getar bangunan tipe 1 arah B/T dan U/S masing-masing sebesar 1,128 detik dan 1,100 detik, sedangkan untuk SMF tipe 2 yaitu 1,262 detik dan 0,791 detik. Berikut hasil analisis struktur yang dihitung dengan bantuan program ETABS untuk perencanaan kekuatan balok-kolom SMF.

Perencanaan balok pada sistem SMF ditentukan berdasarkan kekuatan lentur perlu yang ditinjau berdasarkan kombinasi beban terfaktor menurut peraturan ASCE/SEI 7 (ASCE, 2010) sesuai dengan hasil perbandingan analisis struktur pada Gambar 6 dan 7 berikut ini:

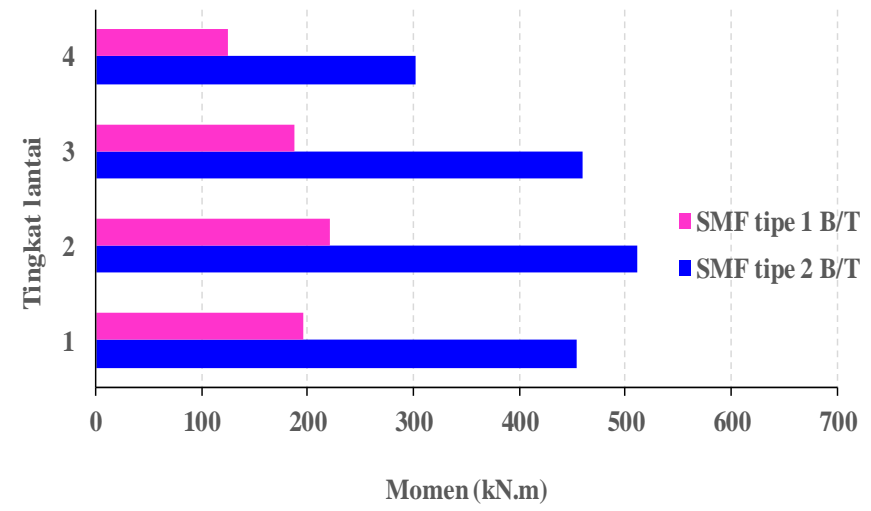

Gambar 6. Perbandingan momen di balok SMF B/T 


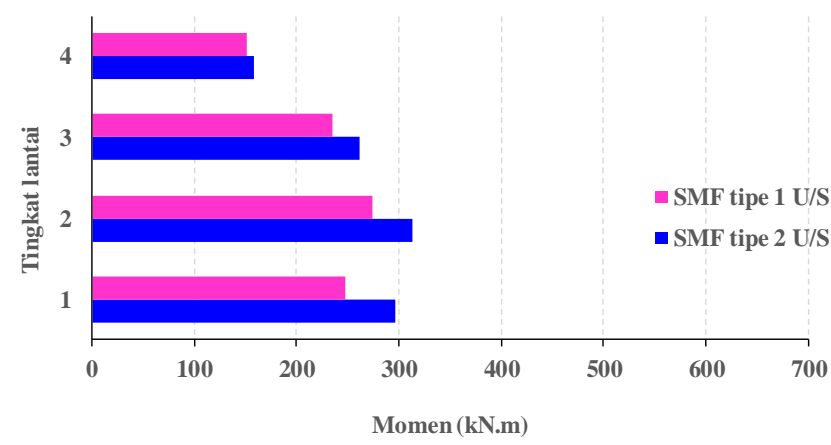

Gambar 7. Perbandingan momen di balok SMF U/S

Kekuatan perlu kolom SMF harus direncanakan pada kombinasi beban gaya aksial dan lentur menurut peraturan ANSI/AISC 360 (AISC, 2010a), sesuai dengan hasil analisis yang diperlihatkan pada Gambar 8 dan Gambar 9. Proporsi hubungan balok-kolom pada sistem SMF merupakan hal penting yang diperhatikan dalam desain dengan beban yang bekerja harus ditentukan berdasarkan prinsip kapasitas desain menurut konsep perencanaan strong column/weak beam. Berdasarkan peraturan gempa ANSI/AISC 341 (AISC, 2010b), rasio yang dihasilkan dari kapasitas momen plastis kolom terhadap balok harus memenuhi Persamaan 1 berikut ini:

$$
\frac{M^{*}{ }_{p c}}{M^{*}{ }_{p b}} \geq 1
$$

di mana $M_{p c}^{*}$ adalah total keseluruhan kapasitas momen plastis kolom, sedangkan $M_{p b}^{*}$ adalah total keseluruhan kekuatan lentur balok yang direncanakan di lokasi sendi plastis.

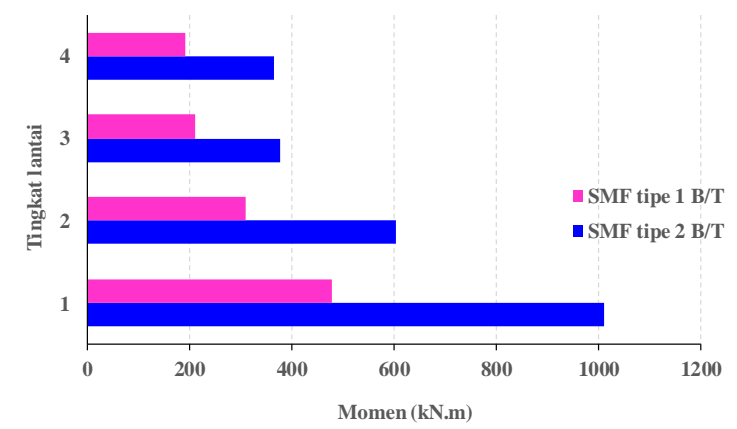

Gambar 8. Perbandingan momen di kolom SMF B/T

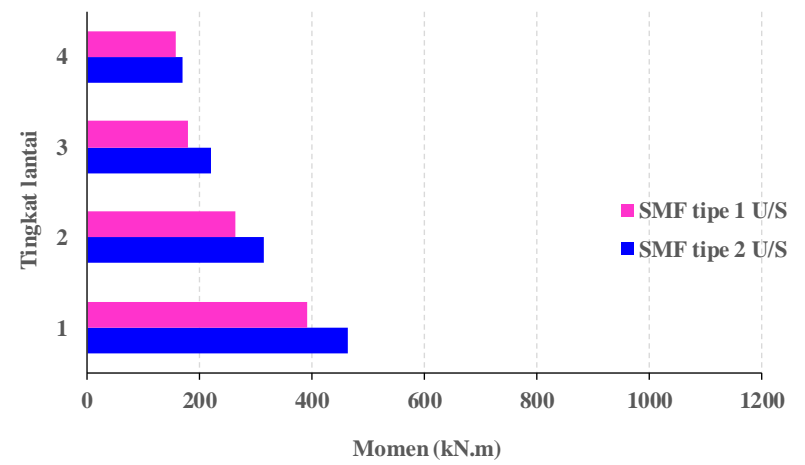

Gambar 9. Perbandingan momen di kolom SMF U/S 


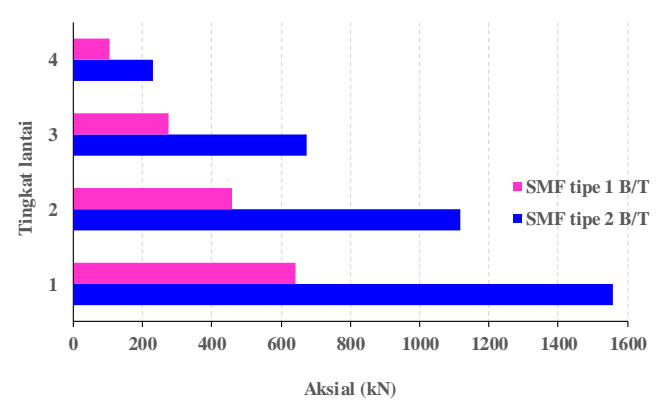

Gambar 10. Perbandingan gaya aksial di kolom SMF B/T

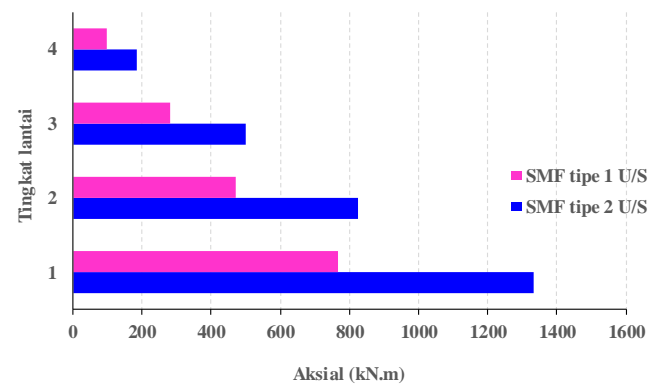

Gambar 11. Perbandingan gaya aksial di kolom SMF U/S

Adapun hasil yang diberikan terhadap perencanaan modifikasi sistem SMF berupa volume keseluruhan struktur bangunan termasuk penahan gravitasi selain lantai beton sesuai dengan Gambar 12 berikut ini:

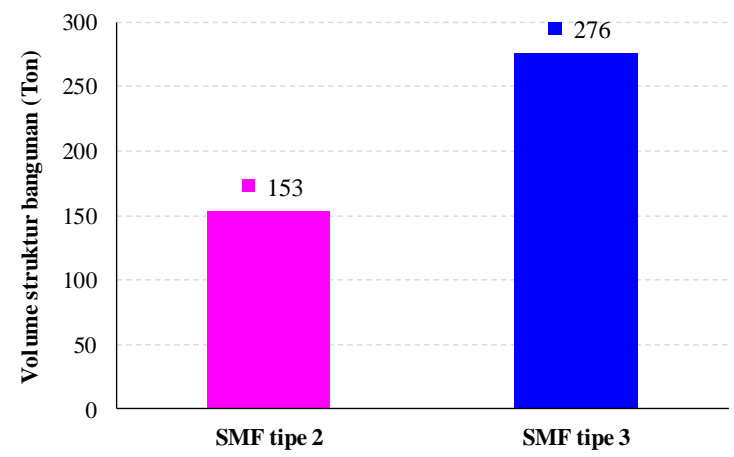

Gambar 12. Perbandingan volume struktur sistem SMF

Dari hasil perbandingan volume sesuai Gambar 5, bahwa konfigurasi struktur SMF dengan panjang bentang antar kolom yang pendek yaitu tipe 1 memberikan nilai volume yang lebih ekonomis. Sedangkan konfigurasi lainnya pada tipe 2, adanya pengaruh balok sebagai penahan gravitasi yang lebih dominan terhadap ketahanan lentur. Dengan konsep strong column/weak beam, maka dimensi kolom memberikan profil baja dengan volume yang lebih menentukan.

\section{SISTEM SPECIAL PLATE SHEAR WALLS}

Sistem special plate shear walls (SPSW) terdiri dari dinding pengisi (infill plates) berupa pelat baja yang dibatasi oleh sistem rangka pemikul momen yang dikenal sebagai boundary elements. Boundary elements merupakan fungsi dari komponen balok yang disebut sebagai horizontal boundary element (HBE) dan kolom yaitu vertical boundary element (VBE) seperti yang diperlihatkan pada Gambar 2. Kekuatan batas yang dihasilkan pada sistem SPSW ini adalah untuk menghasilkan kondisi leleh geser yang direncanakan pada keseluruhan pelat baja di tiap 
tingkat lantai dengan memperbolehkan terjadinya sendi plastis di kedua ujung HBE. Mekanisme gaya-gaya yang diharapkan terjadi pada sistem ini saat kondisi pasca tekuk elastis untuk membangkitkan aksi tarik yang dihasilkan dari penggunaan pelat baja tipis.

Peraturan ANSI/AISC 341 (AISC, 2010b) memberikan metode perencanaan alternatif berdasarkan prinsip kapasitas desain untuk memperkirakan nilai maksimum dalam menghasilkan gaya-gaya yang dikenakan pada boundary elements. Salah satu metode alternatif yang diusulkan adalah dengan prosedur combined plastic and linear analysis. Perencanaan ditinjau terhadap distribusi beban yang merepresentasikan kondisi leleh pelat baja di tiap tingkat lantai, kekuatan lentur plastis HBE, gaya aksial HBE, dan gaya lateral yang dihitung untuk keruntuhan sistem, serta reaksi tumpuan yang dihasilkan sesuai dengan Persamaan 2 berikut ini:

$$
\sum_{i=1}^{n_{s}} F_{i} H_{i}=\underbrace{\sum_{i=0}^{n_{s}} M_{p r l i}+\sum_{i=0}^{n_{s}} M_{p r r i}}_{\text {Sendi plastis HBE }}+\underbrace{\sum_{i=0}^{n_{s}} \frac{1}{2}\left(t_{w i}-t_{w i+1}\right) F_{y p} L H_{i} \sin \left(2 \alpha_{i}\right)}_{\text {Leleh pelat baja }}
$$

Studi kasus yang direncanakan pada sistem SPSW ini, ditinjau berdasarkan sistem SMF tipe 2 dengan hasil perhitungan keseluruhan struktur menunjukkan volume yang tidak ekonomis pada konfigurasi bentang kolom yang panjang. Dalam memperlihatkan potensi penggunaan sistem SPSW ini, maka strategi yang dilakukan dengan penggantian sistem penahan seismik untuk arah B/T menjadi sistem SPSW, sedangkan arah U/S tetap sesuai yang diperlihatkan pada Gambar 13 . Adanya pelat baja yang direncanakan khusus terhadap keseluruhan gaya geser desain, $V$, diharapkan dapat menjadi solusi terhadap permasalahan kolom SMF yang ditentukan berdasarkan prinsip strong column/weak beam.

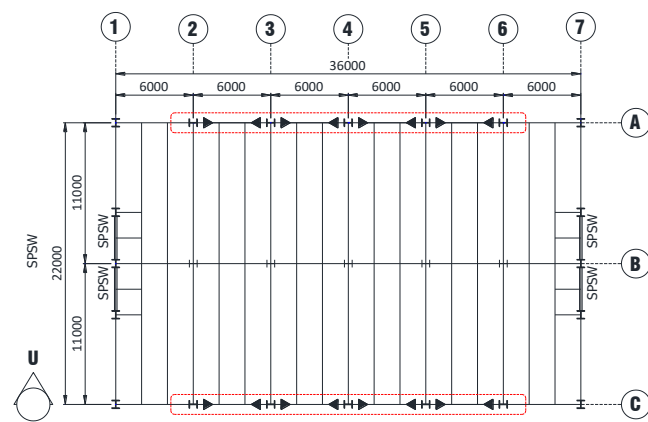

Gambar 13. Denah bangunan sistem SPSW

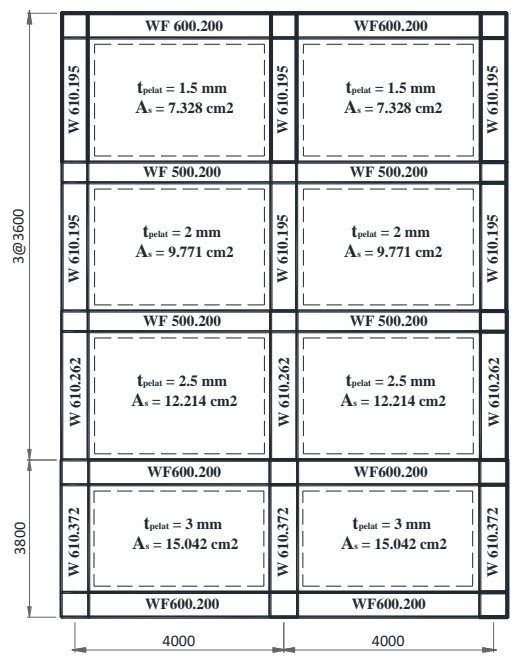




\section{Gambar 14. Desain sistem SPSW}

Beban gempa dihitung menurut peraturan ASCE/SEI 7 (ASCE, 2010) dengan faktor modifikasi respons, $R=7$, faktor kuat lebih sistem, $\Omega_{0}=2$, dan faktor pembesaran defleksi, $C_{d}=6$. Nilai $C_{s}$ yang direncanakan pada sistem ini sebesar 0,087143 dengan periode fundamental yang dihitung yaitu 0.55 detik. Massa tingkat lantai yang digunakan sama terhadap sistem SMF, sehingga dengan prosedur gaya statik ekivalen besaran beban lateral yang direncanakan sesuai Tabel 5 berikut ini:

Tabel 5. Beban gempa desain sistem SPSW

\begin{tabular}{lllllllll}
\hline Lantai & $h_{i}(\mathrm{~m})$ & $W_{i}(\mathrm{~kg})$ & $W_{i} h_{i}(\mathrm{~kg} \cdot \mathrm{m})$ & $W_{i} h_{i}^{k}(\mathrm{~kg} . \mathrm{m})$ & $C_{v x}$ & $F_{i}(\mathrm{kN})$ & $V_{i}(\mathrm{kN})$ & $V_{\mathrm{SPSW}}(\mathrm{kN})$ \\
\hline 4 & 14600 & 328710 & 322115.47 & 4992425.781 & 0.292 & 467.798 & - & - \\
3 & 11000 & 441587 & 524135.74 & 6034036.937 & 0.353 & 565.399 & 467.798 & 123.644 \\
2 & 7400 & 441587 & 524135.74 & 4019231.068 & 0.235 & 376.609 & 1033.198 & 273.085 \\
1 & 3800 & 444934 & 527520.18 & 2043325.165 & 0.120 & 191.463 & 1409.806 & 372.627 \\
Dasar & & 1656818 & & 17089018.95 & 1 & - & 1601.27 & 423.233 \\
\hline
\end{tabular}

Dalam perencanaan sistem SPSW, gaya geser yang disebutkan pada Tabel 5 digunakan untuk perencanaan ketebalan pelat baja, selanjutnya dengan menggunakan prosedur combined plastic and linier analysis (CP+LA) yang diusulkan oleh Berman dan Bruneau (2008) dan tahapan perhitungan yang telah disebutkan pada peraturan ANSI/AISC 341 Commentary F5 (AISC, 2010b), maka didapatkan besaran gaya yang dikenakan pada boundary elements sesuai Tabel 6 dan 7 berikut ini:

Tabel 6. Beban gempa desain sistem SPSW

\begin{tabular}{lllllllll}
\hline Lantai & $t_{i}(\mathrm{~mm})$ & $F_{y}(\mathrm{MPa})$ & $R_{y}$ & $\alpha\left(^{\circ}\right)$ & $\omega_{y c}(\mathrm{kN} / \mathrm{m})$ & $\omega_{x c}(\mathrm{kN} / \mathrm{m})$ & $\omega_{y b}(\mathrm{kN} / \mathrm{m})$ & $\omega_{x b}(\mathrm{kN} / \mathrm{m})$ \\
\hline 4 & 1.5 & 230 & 1.3 & 42.882 & 207.682 & 240.818 & 223.637 & 207.682 \\
3 & 2 & 230 & 1.3 & 41.983 & 267.565 & 330.435 & 297.343 & 267.565 \\
2 & 2.5 & 230 & 1.3 & 41.368 & 370.751 & 326.495 & 421.005 & 370.751 \\
1 & 3 & 230 & 1.3 & 41 & 444.148 & 386.173 & 510.827 & 444.148 \\
\hline
\end{tabular}

Tabel 7 Gaya gempa untuk keruntuhan sistem SPSW

\begin{tabular}{llllllll}
\hline Lantai & $h(\mathrm{~mm})$ & $H_{i}(\mathrm{~mm})$ & $L_{i}(\mathrm{~mm})$ & $M_{p r l}(\mathrm{kN} . \mathrm{m})$ & $M_{p r r}$ & $F_{i}(\mathrm{kN})$ & $V_{i}(\mathrm{kN})$ \\
\hline 4 & - & - & 4000 & 1187.361 & 1187.361 & 563.965 & - \\
3 & 3600 & 14600 & 4000 & 786.24 & 853.185 & 681.63 & 564 \\
2 & 3600 & 11000 & 4000 & 760.728 & 827.672 & 454.03 & 1246 \\
1 & 3600 & 7400 & 4000 & 963.778 & 1086.742 & 230.823 & 1700 \\
Dasar & 3800 & 3800 & 4000 & 1187.361 & 1187.361 & - & 1930 \\
\hline
\end{tabular}

Purba dan Bruneau (2012), memberikan persamaan terhadap ukuran HBE yang ditinjau terhadap kondisi leleh keseluruhan pelat baja tanpa membangkitkan sendi plastis yang dapat terjadi di luar pertemuan HBE-VBE. Persamaan yang dimaksud berupa nilai minimum penampang modulus plastis HBE sesuai dengan Persamaan 3 berikut ini:

$$
Z_{i}=\frac{\omega_{y b i} L_{b}{ }^{2}}{4 F_{y b}}
$$


di mana $L_{b}$ adalah Panjang bentang HBE yang diukur dari sayap kolom, sedangkan $F_{y b}$ adalah tegangan leleh minimum HBE, dan $\omega_{y b}$ yaitu komponen vertikal dari tegangan leleh pelat baja sesuai dengan Persamaan 4 berikut ini:

$\omega_{y b i}=F_{y p} t_{p i} \cos ^{2} \alpha$

di mana $F_{y p}$ adalah tegangan leleh minimum pelat baja, $t_{p i}$ adalah ketebalan pelat baja, serta $\alpha$ adalah sudut yang dibentuk pelat saat kondisi tarik. Meskipun HBE telah memenuhi Persamaan 3 ini, tinjauan lainnya berupa resultan komponen vertikal dan horizontal akibat perbedaan tebal pelat baja saat kondisi leleh harus dihitung dalam menghasilkan kekuatan perlu HBE. Kekuatan perlu HBE harus direncanakan terhadap kombinasi pembebanan terfaktor saat kondisi leleh pelat baja, $\omega_{x b}$ dan $\omega_{y b}$, dan beban gravitasi sesuai dengan hasil analisis yang telah dibandingkan terhadap sistem SMF berikut ini:

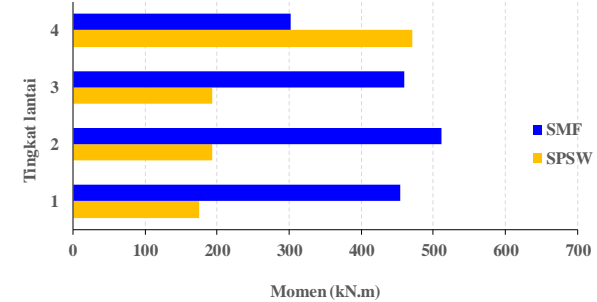

Gambar 15. Perbandingan momen pada sistem SMF dan SPSW

Perencanaan VBE harus ditinjau terhadap gaya lateral yang menyebabkan mekanisme keruntuhan sistem SPSW sesuai yang diperlihatkan pada Tabel 7. Menurut peraturan ANSI/AISC 341 (AISC, 2010b), hasil analisis dengan prinsip kapasitas desain yang diperlihatkan pada diagram free-body VBE sesuai Gambar 16 dengan prosedur $\mathrm{CP}+\mathrm{LA}$ merupakan nilai minimum yang harus direncanakan pada VBE. Kondisi ini menunjukkan bahwa VBE harus tetap dalam kondisi elastis saat tercapainya pelelehan di keseluruhan pelat baja termasuk terbentuknya sendi plastis di HBE.

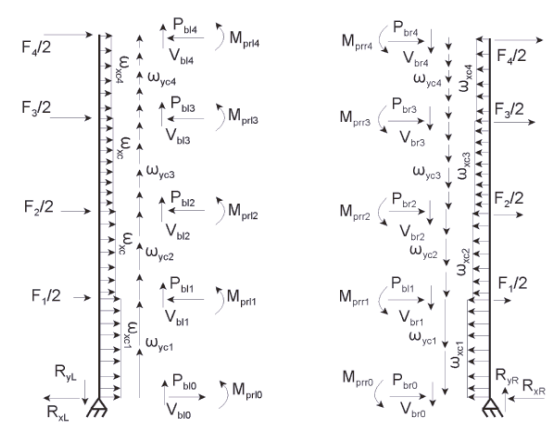

Gambar 16. Diagram free-body VBE (ANSI/AISC, 2010b)

Gaya-gaya yang bekerja pada VBE merupakan hasil pengembangan model elastis VBE dengan tumpuan springs yang merepresentasikan kekuatan aksial HBE. Berikut hasil analisis VBE dengan perbandingan momen dan aksial terhadap sistem SMF sesuai Gambar 17 dan 18 ini: 


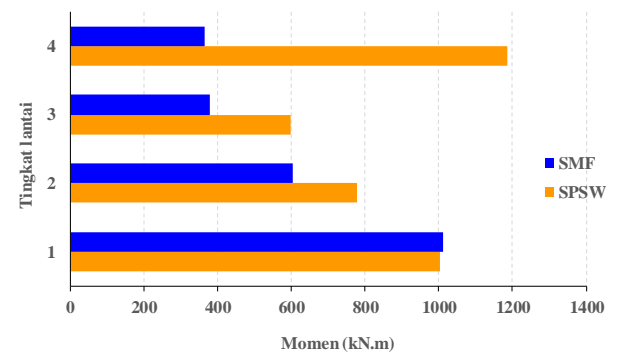

Gambar 17. Perbandingan momen pada sistem SMF dan SPSW

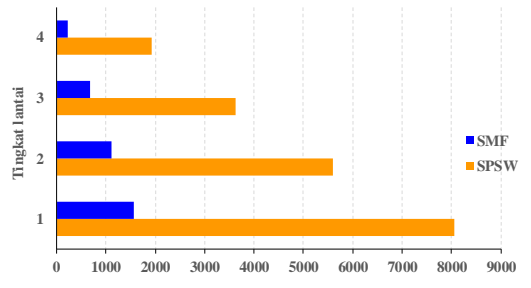

Aksial (kN)

Gambar 18. Perbandingan gaya aksial pada sistem SMF dan SPSW

Adapun hasil yang diperlihatkan pada perbandingan perencanaan sistem SPSW dan SMF berupa volume keseluruhan struktur bangunan termasuk penahan gravitasi sesuai dengan Gambar 19 berikut ini:

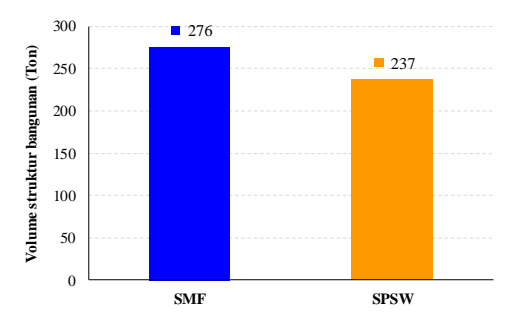

Gambar 19. Perbandingan volume struktur sistem SMF dan SPSW

Dari hasil perbandingan perencanaan sesuai Gambar 19, sistem SPSW dapat menjadi alternatif pada penggunaan konfigurasi struktur bangunan dengan bentang antar kolom yang panjang karena menghasilkan volume yang lebih ekonomis. Pelat baja yang berfungsi sebagai lokasi disipasi energi gempa dapat menjadi solusi pada permasalahan kolom di sistem SMF. Meskipun demikian, momen kopel yang terjadi berupa gaya aksial tarik dan tekan di tumpuan VBE dapat mempengaruhi sistem fondasi.

\section{KESIMPULAN DAN SARAN}

\section{Kesimpulan}

Berdasarkan hasil perbandingan perencanaan yang dilakukan pada penelitian ini dapat diambil beberapa kesimpulan sebagai berikut:

1. Konfigurasi struktur sistem SMF dengan bentang antar kolom yang pendek menghasilkan volume yang lebih ekonomis bila dibandingkan dengan sistem SPSW, sedangkan pada bentang kolom yang panjang sistem SPSW dapat menjadi alternatif.

2. Pada sistem SMF dengan konfigurasi bentang antar kolom yang panjang, pengaruh beban gravitasi pada balok lebih dominan bila dibandingkan terhadap beban lateral (seismik), sehingga volume yang dihasilkan pada sistem ini menjadi tidak ekonomis untuk memenuhi persyaratan strong column-weak beam.

\section{Saran}


Saran yang dapat diberikan dari perbandingan perencanaan ini sebagai berikut:

1. Variasi tinggi bangunan dapat dipelajari lebih lanjut.

2. Interaksi sistem fondasi terhadap sistem SPSW untuk desain bangunan baja tahan gempa perlu dipelajari lebih lanjut.

\section{REFERENSI}

AISC (2006), Steel Plate Shear Walls (ANSI/AISC Steel Design Guide 20), American Institute of Steel Construction, Chicago, Illinois

ASCE (2010), Minimum Design Loads for Buildings and Other Structures (ASCE/SEI 7-10), American Society of Civil Engineers, Reston, Virginia

AISC (2010a), Specification for Structural Steel Buildings (ANSI/AISC 360-10), American Institute of Steel Construction, Chicago, Illinois

AISC (2010b), Seismic Provision for Structural Steel Buildings (ANSI/AISC 341-10), American Institute of Steel Construction, Chicago, Illinois

AISC (2010c), Prequalified Connection for Special and Intermediate Steel Moment Frames for Seismic Applications (ANSI/AISC 358-10), American Institute of Steel Construction, Chicago, Illinois

Berman, J. W., Bruneau, M. 2008. Capacity Design of Vertical Boundary Elements in Steel Plate Shear Walls, Engineering Journal, First Quarter, 2008

Moestopo, M. (2012), Struktur Bangunan Baja Tahan Gempa, Short Course Seminar Himpunan Ahli Konstruksi Indonesia (HAKI), Hotel Borubudur, Indonesia

Purba, R., Bruneau, M. (2012), Case Study on the Impact of Horizontal Boundary Elements Design on Seismic Behavior of Steel Plate Shear Walls, Journal of Structural Engineering, American Society of Civil Engineers, Reston, Virginia 